\title{
Presumed domatia are actually extrafloral nectaries on leaves of Anacardium humile (Anacardiaceae)
}

\author{
Ana Paula Stechhahn Lacchia ${ }^{1}$, Elisabeth Emilia Augusta Dantas Tölke ${ }^{2,4}$, Diego Demarco ${ }^{3}$ \\ \& Sandra Maria Carmello-Guerreiro ${ }^{2}$
}

\begin{abstract}
Presumed domatia are actually extrafloral nectaries on leaves of Anacardium humile (Anacardiaceae), a species from the Brazilian savannah, is associated with foraging ants, which leads to the description of the structure of its leaves as domatia. However, the ants collect secretions on the leaves, a phenomenon that inspired us to elucidate this structure. To this end, we conducted an analysis of the distribution, micromorphology, anatomy and histochemistry of these supposed domatia. They are located in the axil of thicker leaf veins and are composed of glandular trichomes which exude glucose; they are, therefore, described here as extrafloral nectaries (EFNs). The nectariferous trichomes are located at the same level as the other epidermal cells on young leaves, while in mature leaves they were found in depressions of the leafblade. The secretory activity of EFNs is limited to juvenile phases, becoming degenerated in mature leaves. Carbohydrates and lipophilic compounds were detected in the produced secretion. It can be concluded that the presence of ants foraging leaves to collect from EFNs indicates a mutualistic interaction, with the plant providing a sugar resource to the ants in return for protection against herbivory since they are present in developing leaves.
\end{abstract}

Key words: Cashew, extrafloral nectary, glandular trichomes, histochemistry, nectar.

\section{Resumo}

Supostas domácias foliares de Anacardium humile (Anacardiaceae) são na realidade nectários extraflorais Anacardium humile, uma espécie do cerrado brasileiro, está associada a formigas forrageadoras, o que leva à descrição da estrutura presente em suas folhas como domácias. No entanto, as formigas coletam a secreção das folhas, um fenômeno que inspirou este estudo, que visa justamente elucidar esta estrutura. Por esta razão, foi realizada uma análise da distribuição, micromorfologia, anatomia e histoquímica das supostas domácias. Elas estão localizadas nas axilas das nervuras foliares de maior calibre e são compostas por tricomas glandulares. Os tricomas exsudam glicose, portanto, são descritos aqui como nectários extraflorais (NEFs). Os tricomas nectaríferos estão localizados no mesmo nível que as células da epiderme em folhas jovens, enquanto, nas folhas maduras, foram encontradas nas depressões da lâmina foliar. A atividade secretora nos NEFs é limitada a fases juvenis, degenerando em folhas maduras. Carboidratos e substâncias lipofílicas foram detectados na secreção produzida. Pode-se concluir que a presença de formigas forrageando folhas para coleta nos NEFs indica uma interação mutualística, com a planta fornecendo recursos para as formigas em troca de proteção contra herbivoria, uma vez que as mesmas estão presentes em folhas ainda em desenvolvimento.

Palavras-chave: Caju, nectário extrafloral, tricomas glandulares, histoquímica, néctar.

\section{Introduction}

The genus Anacardium L. is known for cashew production, a nutritious edible nut produced by the cashew tree $A$. occidentale L. (Vieira et al. 2014). There are 11 species in this genera, eight of them in Brazil (Silva-Luz \& Pirani
2014). One of these species is Anacardium humile A. St.-Hil., occurring in the cerrado sensu lato of Brazil (Brazilian savannah) in the states of Bahia, Distrito Federal, Goiás, Mato Grosso, Mato Grosso do Sul, Minas Gerais, Paraná, Piauí, Rondônia, São Paulo and Tocantins. This species is also

\footnotetext{
${ }^{1}$ Universidade Estadual da Paraíba, Campus I, Depto. Biologia, Centro de Ciências Biológicas e da Saúde, 58109-790, Campina Grande, PB, Brasil.

${ }^{2}$ Universidade Estadual de Campinas, Depto. Biologia Vegetal, Programa de Pós-graduação em Biologia Vegetal, Inst. Biologia, C.P. 6109, 13083-970, Campinas, SP, Brasil.

${ }^{3}$ Universidade de São Paulo, Depto. Botânica, Inst. Biociências, 05508-090, São Paulo, SP, Brasil.

${ }^{4}$ Author for correspondence: elisabeth.tolke@gmail.com
} 
known locally as "cajuzinho-do-cerrado," "caju," "cajueiro-do campo," "caju-de-árvore-do-cerrado" and "cajuhy" (Naranjo \& Pernía 1990; Silva-Luz \& Pirani 2014).

This genus comprises subshrubs or trees, evergreen. The leaves are alternate, simple, sessile to petiolate, entire, chartaceous to coriaceous, and domatia are usually described in its species (Pell et al. 2011). Anacardium humile has branches spread near the soil surface and, as a consequence of its architecture, competes with others for space. In addition, it is threatened, considered rare and, as a result, legally protected (CEMIG 2001). The oil found in its nuts is volatile and corrosive, containing anacardic acid and cardol, which are used as medicinal antiseptics (Barroso et al. 1999). In addition to its medicinal and industrial uses due to its antiulcerogenic properties (Luiz-Ferreira et al. 2008; Luiz-Ferreira et al. 2010), A. humile is used as a food source for local populations who consume the peduncle and fruits (Corrêa 1984; Almeida et al. 1998).

Anacardium humile, like others species of this genus, is associated with foraging ants. For this reason, the structures present in the axils of the leaf veins in species of this genus have been described as domatia (Silva-Luz 2011). According to Beatle \& Hughes (2002), a domatium is a "plant structure that appears to be specific adaptations for ant occupation, often formed by the hypertrophy of internal tissue at particular locations in the plant, creating internal cavities attractive to ants." The presence of foraging ants led to an inquiry into whether these structures were indeed domatia since the ants just seem to visit the plant to collect some secretion.

Given this, the ants could be collecting nectar since extrafloral nectaries on the axil of leaf veins have been reported for other families, e.g., Fabaceae and Bignoniaceae (Díaz-Castelazo et al. 2005; Nogueira et al. 2012). Extrafloral nectaries are specialised tissues on vegetative structures that secrete nectar (Durkee 1982; Elias 1983), which is a source of nutrients for some organisms (Ruhren \& Handel 1999; Melo et al. 2010; Marazzi et al. 2013) since it is rich in sugars, amino acids, vitamins, water and other organic compounds (Bentley 1977; Baker 1978; Durkee 1982; Nicolson \& Thornburg 2007). Several studies have associated extrafloral nectaries (EFNs) with plant protection against herbivory (Vesprini et al. 2003; Oliveira \& Freitas 2004; Marazzi et al. 2013). However, this protection sometimes depends on the positive association between plant and ants, which are attracted by the nectar produced by the EFNs (Oliveira \& Freitas 2004).

Plants with EFNs have already been described in more than 3000 species distributed across 108 botanical families (Weber \& Keeler 2013). Approximately $25 \%$ of woody species in the southeastern Brazilian Cerrado had EFNs, while $21-26 \%$ of species in the midwestern Cerrado areas had this structure (Oliveira \& Leitão-Filho 1987; Oliveira \& Oliveira-Filho 1991; Machado et al. 2008). However, Paiva et al. (2001) affirmed that such numbers are underestimated for the Cerrado.

However, anatomical studies of Anacardium are relatively rare. In Anacardium occidentale L. the structure and ultrastructure of secretory ducts were analysed (Nair et al. 1983). In Anacardium humile underground organs were examined (Naranjo \& Pernía 1990), and the flower and fruit canals were studied ultrastructurally (Lacchia \& Carmello-Guerreiro 2009). Extrafloral nectaries have already been cited for Anacardiaceae species, e.g., on leaves of Anacardium occidentale (Wunnachit et al. 1992; Rickson \& Rickson 1998). Glandular trichomes were reported on the upper part of the petiole or near the transition between leaf blade and petiole and on stipules and bracts of Holigarna arnottiana Hook. f., H. ferruginea Marchand, H. helferi Hook. f, and H. grahamii (Wight) Kurz (Bentley \& Elias 1983).

The aim of this study was to determine whether the structures found in the axil of leaf veins of A. humile are secretory structures and, if so, to check the nature of the secretion produced.

\section{Material and Methods}

Samples were collected in different populations of Cerrado areas in the state of São Paulo, Brazil, including the Biological Reserve and Experimental Station of Moji Guaçu, Fazenda Palmeira da Serra in Pratânia and a Cerrado fragment in Botucatu. Vouchers were deposited in the UEC herbarium: Lacchia A. 13 (UEC); Lacchia A. 8 (UEC); Lacchia A. 18, 19, 20, 21 (UEC).

To confirm the presence of glucose in the secretion, a glucostrip (Sensi 10) was used in droplets collected from the presumed domatia.

Leaves (2-27 cm in length) of A. humile were fixed in FAA (formalin, acetic acid and $50 \%$ ethanol) for $24 \mathrm{~h}$ (Johansen 1940) and BNF (buffered neutral formalin) for $48 \mathrm{~h}$ (Lillie $1965)$ and stored in $70 \%$ ethanol. Leaves of different lengths were observed under a SMZ-U 
stereomicroscope in order to locate leaf trichomes. For anatomical studies leaves around 2, 7, 11, and $20 \mathrm{~cm}$ in length were isolated, dehydrated in butanol series, and embedded in Paraplast Plus ${ }^{\circledR}$ (Leica Biosystems Richmond, Inc.). Transversal and longitudinal sections $12-18 \mu \mathrm{m}$ thick were obtained using a Microm HM340E Rotary Microtome. The sections were stained with $1 \%$ safranin, $1 \%$ crystal violet and $1 \%$ orange $\mathrm{G}$ in clove oil (Fleming's triple stain) (Johansen 1940). Permanent slides were mounted in Permount ${ }^{\mathrm{TM}}$ synthetic resin (Fisher Chemicals).

For the histochemical analyses, leaves fixed in FAA were used to test for hydrophilic substances, and the materials fixed in BNF were used to test for lipophilic substances. The following histochemical treatments were performed to confirm the presence and composition of the secretion of the presumed domatia: ruthenium red for pectic compounds in mucilage (Gregory \& Bass 1989), tannic acid and ferric chloride for mucilage (Pizzolato 1977), PAS reaction (Periodic Acid-Schiff; pararosanilin C.I. 42510) for carbohydrates (McManus 1948), Sudan black B (C.I. 26150) for lipids (Pearse 1985), Nile blue (C.I. 51180) for neutral and acidic lipids (Cain 1947), copper acetate and rubeanic acid for fatty acids (Ganter \& Jollés 1969, 1970) and ferric chloride for phenolic compounds (Johansen 1940).

For the control of tests detecting lipophilic substances, samples were placed in a solution of methanol, chloroform, water, and chloridric acid (66: 33: 4: $1 \mathrm{v} / \mathrm{v}$ ) (High 1984) for $48 \mathrm{~h}$. Afterwards, these samples were fixed in BNF and treated with the stains and reagents mentioned above. Controls for hydrophilic substances followed standard techniques. Images were taken using a SMZ-U stereomicroscope, and photomicrographs were obtained with an Olympus BX51 microscope using Kodak ProImage ASA 100 film.

Leaves 2-20 cm in length fixed in FAA were dehydrated in a graded ethylic series, critical point dried (Balzers CPD-030), and sputter-coated with gold using a Balzers SCD-050 Sputter Coater. Observations were carried out using a Jeol JSM 5800 LV scanning electron microscope (SEM) at $10 \mathrm{kV}$ equipped with a digital camera.

\section{Results}

The presence of glucose was confirmed by the gluco-strip test in droplets collected from the leaves. For this reason, the presumed domatia are extrafloral nectaries. Ants were observed foraging these structures (Fig. 1a), which consist of glandular trichomes organized in groups (Fig. 1be; 2a-d). The glandular trichomes are multicellular and multiseriate (Fig. 2a-d). The glandular head is multiseriate, and the stalk is unicellular (Fig. $2 b-d)$. The number of cell series can vary from two to eight (Fig. 2c) and the number of cells in each series from four to five (Fig. 2c).

These trichomes show different patterns of distribution according to the stage of leaf development. The distribution patterns can be observed in Figure 3a-d and are summarized below:

a) On young leaves (around $2-4 \mathrm{~cm}$ in length): Glandular trichomes occur at the base of

Table 1 - Histochemical tests applied to leaves of Anacardium humile St.Hil. (+: positive result; - : negative result)

\begin{tabular}{llll}
\hline Treatment & Substance & Color & Glandular trichomes \\
\hline Ruthenium red & Acidic mucilage & Pink to red & - \\
Tannic acid and ferric chloride & Mucilage & Black & - \\
PAS reaction & Carbohydrates & Pink to red & + (Fig. 4b) \\
Sudan black B & Lipids & Black/brown & + (Fig. 4c) \\
Nile blue & Acidic lipids & Blue & + (Fig. 4d) \\
Copper acetate and rubeanic acid & Fatty acid & Dark green & + (Fig. 4e) \\
Ferric chloride & Phenolic compounds & Black/brown & + (Fig. 4f)
\end{tabular}


the leaf blade on the adaxial surface at the same level as the neighbouring cells (Fig. 1c). On the abaxial surface they are found in the axils of secondary veins, proximal to midrib.

b) On adult leaves (around $7-11 \mathrm{~cm}$ in length): The distribution of glandular trichomes is similar to the preceding stage (Fig. 1c-d). At this developmental stage, these structures are found in depressions (Fig. 3a) between primary and secondary veins.

c) On mature leaves (around $20 \mathrm{~cm}$ in length): Glandular trichomes can be observed only on the abaxial surface, almost exclusively in depressions located in the axils of thicker secondary veins. Usually, trichomes from these leaves are all senescent (Fig. 1e), but some trichomes still producing secretion were observed, in general, at the apex of the leaf blade.

In addition to the nectar detected by glucostrip, compared with the Fleming's triple stain (Fig. 4a), the glandular trichomes produce carbohydrates (Fig. 4b), lipids (Fig. 4c-e) and phenolic compounds (Fig. 4f). The mucilage test was negative. Thus, these cells produce several metabolites simultaneously (Tab. 1).

\section{Discussion}

The presumed domatia on A. humile leaves, according to the tests carried out, are extrafloral nectaries (EFNs). Indeed, there are cases cited in the literature in which domatia may contain nectaries within their structure (Leroy et al. 2008), but in $A$.
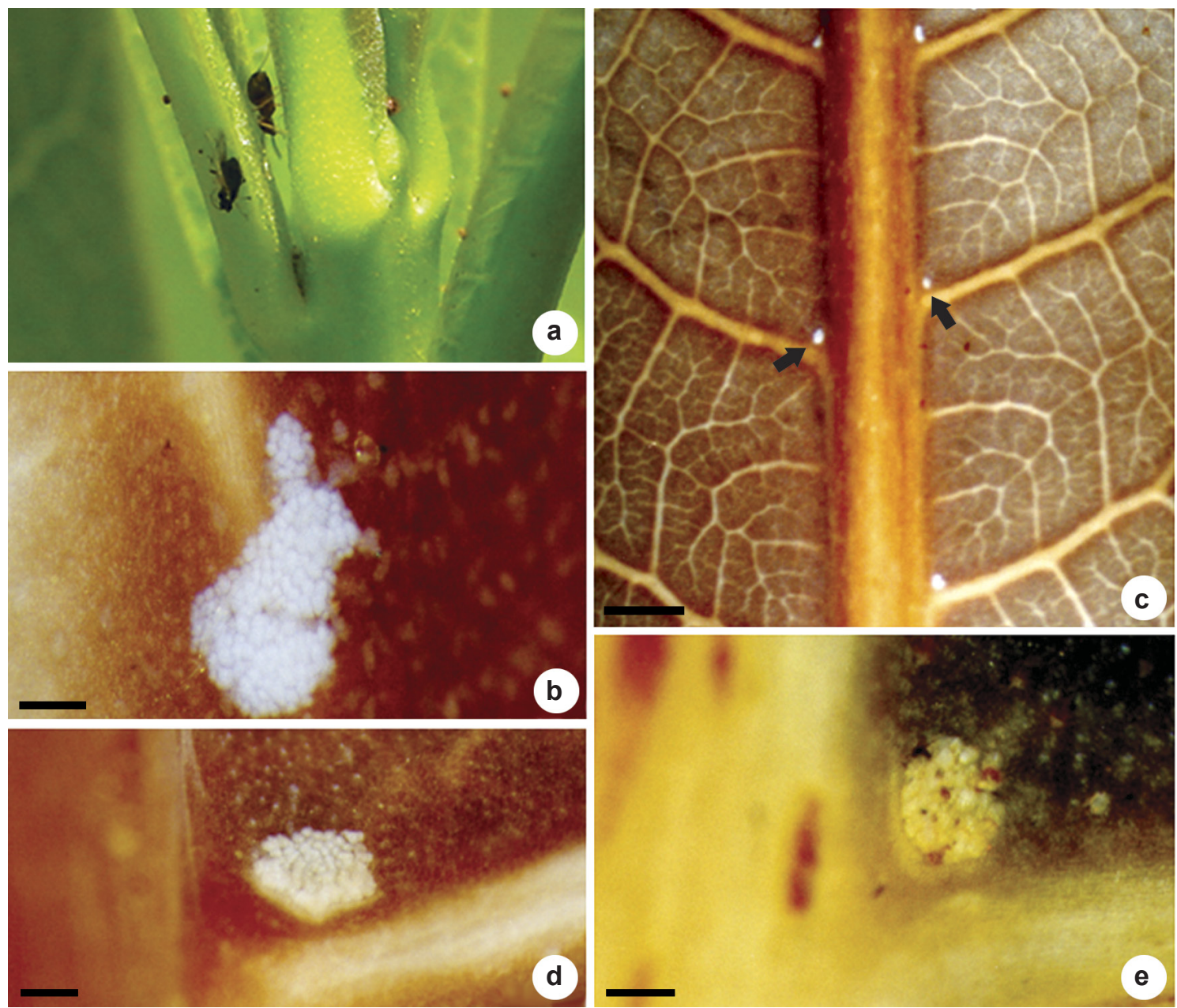

Figure 1 - Leaf of Anacardium humile St.Hil. - a. ants foraging leaves, around $2 \mathrm{~cm}$ in length; b. view of glandular trichomes at the base of the leaf blade on the adaxial surface, leaf around $2 \mathrm{~cm}$ in length; $\mathrm{c}$. view of abaxial surface (arrows indicate the EFNs), leaf around $7 \mathrm{~cm}$ in length; d. detail of laminar depression with the glandular trichomes, leaf around $11 \mathrm{~cm}$ in length; e. senescent trichomes, leaf around $20 \mathrm{~cm}$ in length. Bars: $1.5 \mathrm{~mm}$ (b), $150 \mu \mathrm{m}$ (d-e), $125 \mu \mathrm{m}$ (c). 
humile the structure described offers a resource but does not provide shelter for the foraging ants.

The EFNs are composed of multicellular glandular trichomes and are located in depressions in the axils of leaf veins on one or both of the adaxial and abaxial surfaces, depending on the developmental stage of the leaf. Similarly, their location at the apex, middle and base of the lamina also depends on leaf development. Rickson \& Rickson (1998) observed the same pattern for the location of EFNs in leaves of $A$. occidentale $\mathrm{L}$.

During development there is a reduction in the number of trichomes, but all trichomes are in the same stage of development, which could mean that a large amount of nectar is offered in a short period of time. Other studies confirm our
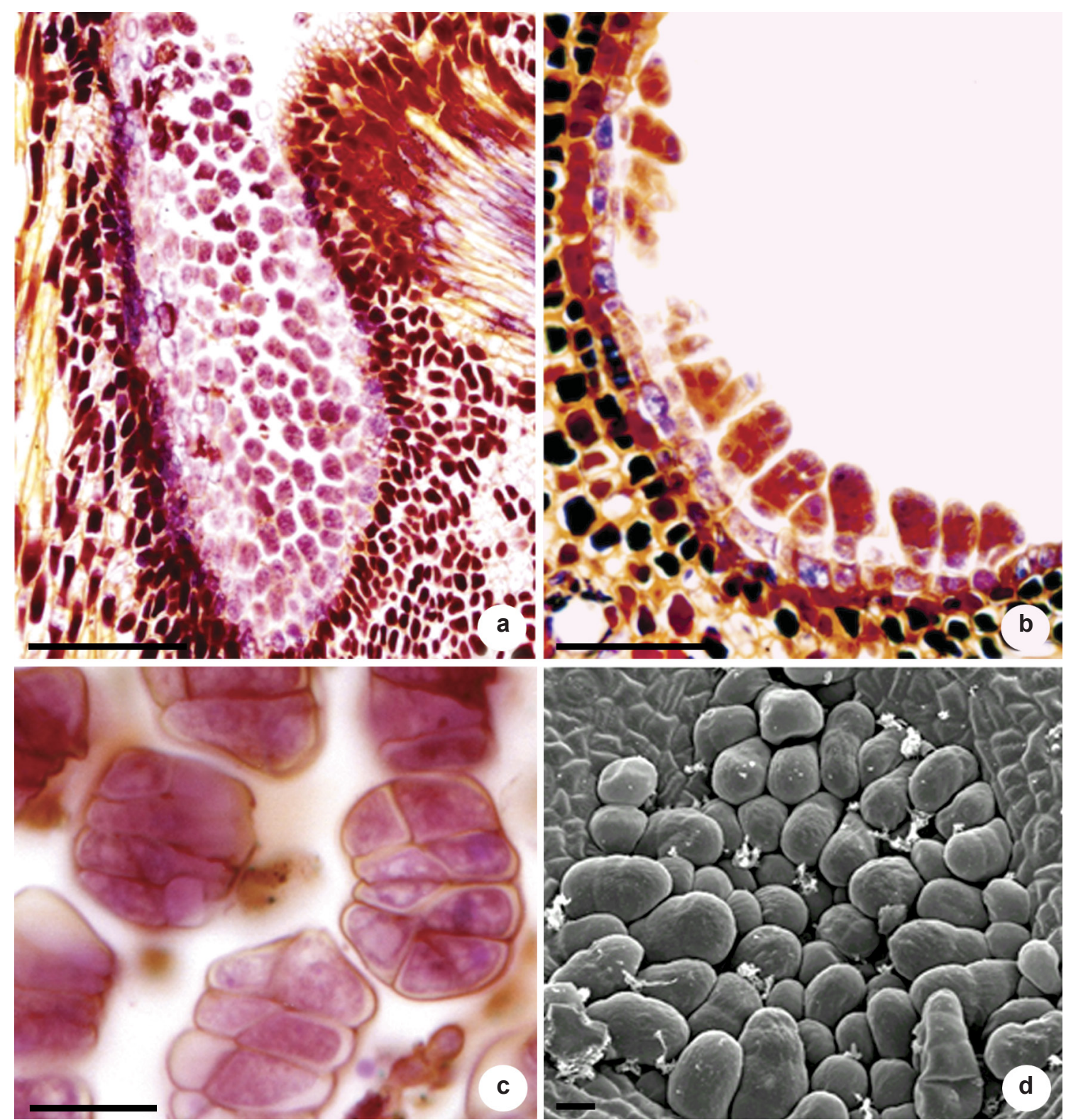

Figure 2 - View of abaxial surface of a leaf of Anacardium humile St.Hil. - a. leaf base with several trichomes in depressions, leaf around $7 \mathrm{~cm}$; b. longisections of the multicellular trichomes, leaf around $7 \mathrm{~cm}$; c. transections of the multiseriate gland head, leaf around $7 \mathrm{~cm}$; d. middle part of the lamina with several glandular trichomes under SEM, leaf around $11 \mathrm{~cm}$. Bars: $150 \mu \mathrm{m}$ (a), $50 \mu \mathrm{m}$ (b), $30 \mu \mathrm{m}$ (c), $10 \mu \mathrm{m}$ (d). 
observations (Elias 1980; Paiva \& Machado 2006) and demonstrate that these leaf areas are more vulnerable to herbivory (Delgado et al. 2011).

Stephenson (1982) reported that nectar production on leaves of Catalpa speciosa Warder ex Engelm. (Bignoniaceae) was distributed among several nectaries, as observed on the abaxial leaf surface in A. humile. According to this same author, the search for nectar by ants foraging portions of the leaf is based on this distribution pattern of EFNs. Using this strategy, more herbivores can be found by ants, thus decreasing herbivory rates on leaves. Similar distribution patterns of nectaries were observed by Morellato \& Oliveira (1994) in Guarea macrophylla Vahl. (Meliaceae) and by Paiva \&Machado (2006) in Hymenaea stigonocarpa Mart. ex Hayne (Fabaceae). The presence of EFNs at different places on the leaves may suggest an adaptive value in terms of herbivory defense since the ants must visit the whole leaf to obtain a certain amount of nectar (Delgado et al. 2011).

Field observations showed that the secretory activity of $A$. humile begins with the distension of the young leaf and increases after total expansion.
This pattern is frequent in EFNs and is also observed in other botanical families, e.g., Fabaceae, Meliaceae and Passifloraceae (Elias 1972, 1980; Elias et al. 1975; Durkee 1982; Morellato \& Oliveira 1994; Paiva et al. 2001; Paiva \& Machado 2006).

Elias (1972) noted that EFNs of Pithecellobium macradenium Pittier (Fabaceae) become inactive in old leaves, as in Maprounea brasiliensis (Delgado et al. 2014). For this reason, the authors hypothesized that the end of secretory activity is associated with the leaf life cycle. However, our observations show that the end of secretory activity of EFNs of $A$. humile coincides with leaf maturity. Therefore, we can conclude that there is no association between EFN activity and the leaf life cycle for this species, as already reported for $A$. occidentale (Rickson \& Rickson 1998) and Hymenaea stigonocarpa (Paiva \& Machado 2006).

The extrafloral nectaries of $A$. humile are composed of several multicellular and multiseriate nectariferous trichomes (Rickson \& Rickson 1998). Such trichomes are also described on petals of this species (Lacchia 2006) and on leaf depressions of
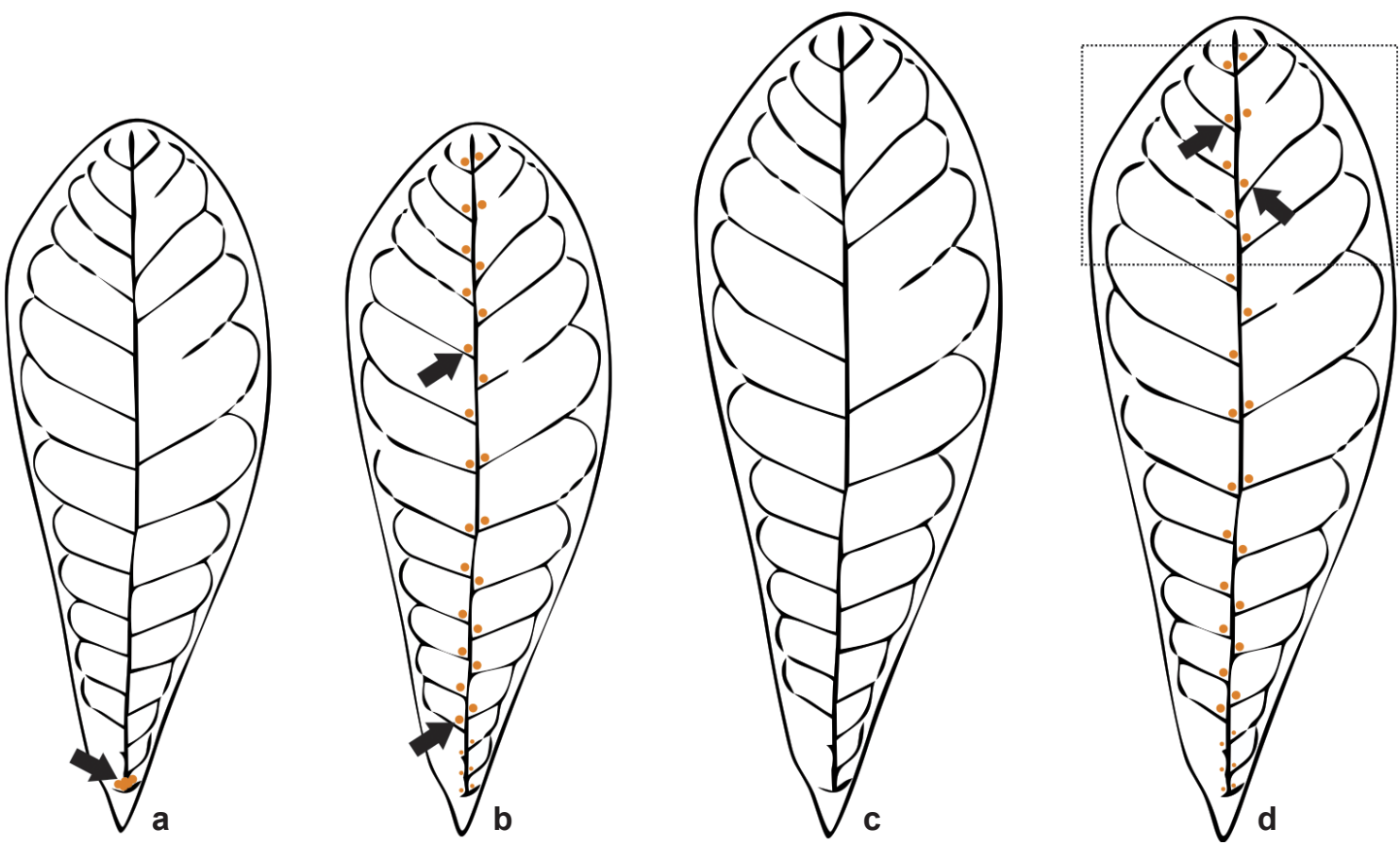

Figure 3 - Location of glandular trichomes on the leaves of Anacardium humile St.Hil. - a. adaxial surface showing the EFNs at the base of the leaf blade (arrow), leaves around 2-11 cm; b. abaxial surface showing the EFNs in the axils of secondary veins, proximal to midrib (arrows), leaves around $2-11 \mathrm{~cm}$; c. adaxial surface of mature leaves without EFNs, leaf around $20 \mathrm{~cm}$ in length; $d$. abaxial surface of mature leaves showing functional EFNs only at the apex of the leaf blade (rectangle) and senescent trichomes on the rest of the lamina, leaf around $20 \mathrm{~cm}$ in length. 
A. corymbosum Barb. Rodr., A. nanum A. St.Hil., A. parvifolium Ducke and A. amapaense J.D. Mitch. (Mitchell \& Mori 1987; Mitchell 1992). These studies did not characterize the secretion composition of the glandular trichomes; however, due to their similar position and morphology in relation to the trichomes found in $A$. humile, we can hypothesize that these trichomes are also EFNs.

In A. occidentale, Rickson \& Rickson (1998) observed that papillate glands cover
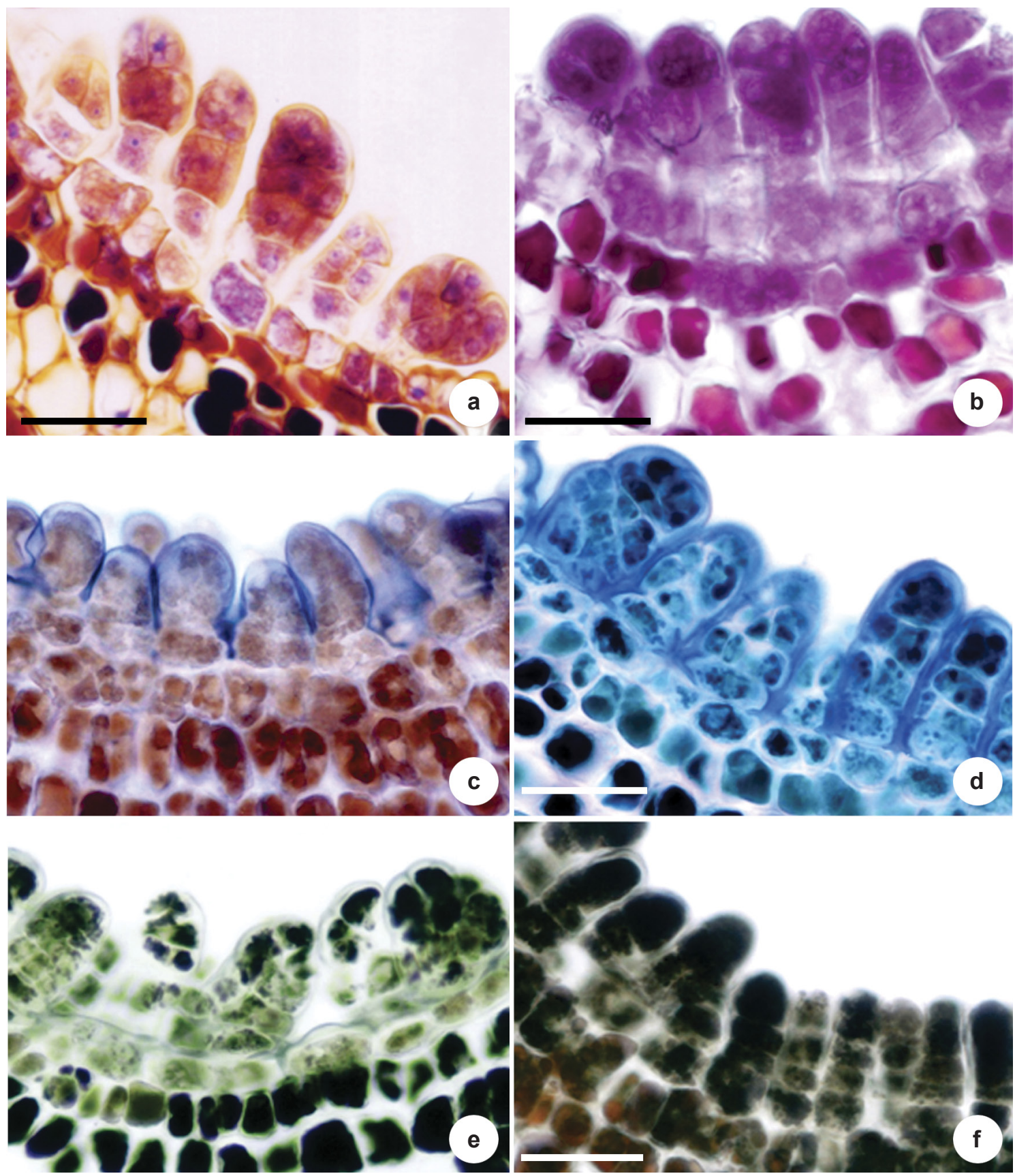

Figure 4 - Histochemical tests compared with normal coloration in leaves of Anacardium humile St.Hil. View of abaxial surface of leaves around $7 \mathrm{~cm}$ in length $-\mathrm{a}$. longisection of the multicellular trichomes with normal coloration; $b$. positive result for carbohydrate; c. positive result for lipids; d. detection of acidic lipids; e. presence of fatty acid; f. positive result for phenolic compounds. Bars: $50 \mu \mathrm{m}$ (a, c, e, f), $30 \mu \mathrm{m}$ (b, d). 
the inner layers of leaf depressions. Although they did not perform chemical or histochemical tests, these authors characterized these papillate cells as producing a nectariferous secretion. The occurrence of EFNs is also recorded for inflorescences and young fruits of $A$. occidentale. Extrafloral nectaries found on inflorescence axes are also composed of several multicellular and multiseriate trichomes, while EFNs from fruits exude the nectar through modified stomata in the exocarp (Wunnachit et al. 1992).

The trichomes of $A$. humile react positively to carbohydrates, phenolic compounds and lipids. Nectar is usually not a homogeneous secretion. In addition to sugar, other compounds in minor amounts, e.g., amino acids, lipids and mineral ions, have already been detected in many species (e.g., amino acids in Erythrina L. species, proteins in Allium porrum L., lipids in Calceolaria L. species, phenolic substancces in Aloe vryheidensis Groenew.) (Lüttge \& Schnepf 1976; Baker 1977; Nicolson \& Thomburg 2007). However, the trichomes of A. humile can be characterized as producing a mixed secretion since several substances were detected using histochemical tests.

Wunnachit et al. (1992) and Rickson \& Rickson (1998) believed that the secretion of probable leaf ENFs of $A$. occidentale could attract ants, thus protecting leaves and fruits against predators. Since several ants were observed foraging EFNs of $A$. humile in our study, it seems likely that these secretory structures play an important role in plant protection by attracting insects that dislodge herbivores, as observed in other studies (Koptur 1984; Oliveira et al. 1999; Katayama \& Suzuki 2003; Oliveira \& Freitas 2004; Rudgers \& Gardener 2004).

Our work is the first to elucidate the true nature of glandular structures present in $A$. humile leaves, widely described as domatia. However, the relationship with ants requires more detailed study.

\section{Acknowledgements}

The authors thank FAPESP (proc. 01/121781, 03/13556-5; Biota/FAPESP proc. 96/12345-5; proc. $n^{\circ} 2014 / 18002-2$ ); and CAPES for their financial support.

\section{References}

Almeida, S.P.; Proença, C.E.B.; Sano, S.M. \& Ribeiro, J.F. 1998. Cerrado: espécies vegetais úteis. EMBRAPA-CPAC, Planaltina. 464p.
Baker, H.G. 1977. Non-sugar chemical constituents of nectar. Apidologie 8: 349-356.

Baker, H.G. 1978. Chemical aspects of the pollination biology of woody plants in the tropics. In: Tomlinson, P.B. \& Zimmerman, M.H. Tropical trees as living systems. Cambridge University Press, Cambridge. Pp. 57-82

Barroso, G.M.; Morim, M.P.; Peixoto, A.L. \& Ichaso, C.L.F. 1999. Frutos e sementes: morfologia aplicada à sistemática de dicotiledôneas. Editora UFV, Viçosa. 443p.

Beattie, A.J. \& Hughes, L. 2002. Ant-plant interactions. In: Herrera, C. \& Pellmyr, O. Plant-animal interactions: an evolutionary approach. Blackwell, Oxford. Pp. 211-235.

Bentley, B.L. 1977. The protective function of ants visiting the extrafloral nectaries of Bixa orellana L. (Bixaceae). Journal of Ecology 65: 27-38.

Bentley, B. \& Elias, T.S. 1983. The biology of nectaries. Columbia University Press, New York. 259p.

Cain, A.J. 1947. The use of Nile blue in the examination of lipids. Quarterly Journal of Microscopical Science 88: 383-392.

CEMIG - Companhia Energética de Minas Gerais. 2001. Guia ilustrativo de plantas do cerrado de Minas Gerais. Assessoria de coordenação ambiental. Nobel, São Paulo. 96p.

Delgado, M.N.; Silva, L.C.; Bao, S.N.; Morais, H.C. \& Azevedo, A.A. 2011. Distribution, structural and ecological aspects of the unusual leaf nectaries of Calolisianthus species (Gentianaceae). Flora 206: 676-683.

Delgado, M.N.; Bao, S.N.; Amaral, L.I.; Rossatto, D.R. \& Morais, H.C. 2014. Extrafloral nectary morphology and the role of environmental constraints in shaping its traits in a common Cerrado shrub (Maprounea brasiliensis A. St.-Hill: Euphorbiaceae). Brazilian Journal of Botany 37: 495-504.

Díaz-Castelazo, C.; Rico-Gary, V.; Ortega, F.; Ángeles, G. 2005. Morphological and secretory characterization of extrafloral nectaries in plants of coastal Veracruz, Mexico. Annals of Botany 96: 1175-1189.

Durkee, L.T. 1982. The floral and extrafloral nectaries of Passiflora. II. The extrafloral nectary. American Journal of Botany 69: 1420-1428.

Elias, T.S. 1972. Morphology and anatomy of foliar nectaries of Pithecellobium macradenium (Leguminosae). Botanical Gazette 133: 38-42.

Elias, T.S. 1980. Foliar nectaries of unusual structure in Leonardoxa africana (Leguminosae), an African obligate myrmecophyte. American Journal of Botany 67: 423-425.

Elias, T.S. 1983. Extrafloral nectaries: their structure and distribution. In: Bentley, B.L. \& Elias, T.S. The Biology of nectaries. Columbia University Press, New York. Pp. 174-203. 
Elias, T.S.; Rozich, W.R. \& Newcombe, L. 1975. The foliar and floral nectaries of Turnera ulmifolia. American Journal of Botany 62: 570-576.

Ganter, P. \& Jollés, G. 1969. Histochimie normale et pathologique. Vol. 1. Gauthier - Villars, Paris. 923p.

Ganter, P. \& Jollés, G. 1970. Histochimie normale et pathologique. Vol. 1. Gauthier - Villars, Paris. 978p.

Gregory, M. \& Baas, P. 1989. A survey of mucilage cells in vegetative organs of the dicotyledons. Israel Journal of Botany 38: 125-174.

High, O.B. 1984. Lipid histochemistry. RMS Microscopy Handbook $n^{\circ}$ 2. Oxford University Press, Oxford. Pp. 1-68.

Johansen, D.A. 1940. Plant Mycrotechnique. McGrawHill, New York. 523p.

Katayama, N. \& Suzuki, N. 2003. Changes in the use of extrafloral nectaries of Vicia faba (Leguminosae) and honeydew of aphids by ants with increasing aphid density. Annals of Entomological Society of America 96: 579-584.

Koptur, S. 1984. Experimental evidence for defense of Inga (Mimosoideae) saplings by ants. Ecology 65: 1787-1793.

Lacchia, A.P.S. 2006. Estruturas secretoras em órgãos vegetativos e reprodutivos de espécies de Anacardiaceae: anatomia, histoquímica e ultraestrutura. Tese de Doutorado. Universidade Estadual de Campinas, Campinas. 264p.

Lacchia, A.P.S. \& Carmello-Guerreiro, S.M. 2009. Aspectos ultra-estruturais dos canais secretores em órgãos vegetativos e reprodutivos de Anacardiaceae. Acta Botatina Brasilica 23: 376-388.

Lerroy, C.; Jauneau, A.; Quilichini, A.; Dejean, A. \& Orivel, J. 2008. Comparison between the anatomical and morphological structure of leaf blades and foliar domatia in the ant-plant Hirtella physophora (Chrysobalanaceae). Annals of Botany 101: 501-507.

Lillie, R.D. 1965. Histopathologic technic and practical histochemistry. McGraw-Hill, New York. 715p.

Luiz-Ferreira, A.; Cola-Miranda, M., Barbastefano, V.; Hiruma-Lima, C.A.; Vilegas, W. \& Brito, A.R.M.S. 2008. Should Anacardium humile St. Hil be used as an antiulcer agent? A scientific approach to the traditional knowledge. Fitoterapia 79: 207-209.

Luiz-Ferreira, A.; Almeira, A.C.A.; Cola, M.; Barbastefano, V.; Almeida, A.B.A.; Batista, L.M.; Farias-Silva, E.; Pellizzon, C.H.; Hiruma-Lima, C.A.; Santos, L.C.; Vilegas, W. \& Brito, A.R.M.S. 2010. Mechanisms of the gastric antiulcerogenic activity of Anacardium humile St. Hil on ethanolinduced acute gastric mucosal injury in rats. Molecules 15: 7153-7166.

Lüttge, U. \& Schnepf, E. 1976. Organic substances. In: Lüttge, U. \& Pitman, M.G. Transport in plants II. Part B: tissues and organs. Springer-Verlag, Berlin. Pp. 244-277.
Machado, S.R.; Morellato, L.P.C.; Sajo, M.G. \& Oliveira, O.S. 2008. Morphological patterns of extrafloral nectaries in woody plant species of the Brazilian cerrado. Plant Biology 10: 660-673.

Marazzi, B.; Bronstein, J.L. \& Koptur, S. 2013. The diversity, ecology and evolution of extrafloral nectaries: current perspectives and future challenges. Annals of Botany 111: 1243-1250.

McManus, J.F.A. 1948. Histological and histochemical uses of periodic acid. Stain Technology 23: 99-108.

Melo, Y.; Machado, S.R. \& Alves, M. 2010. Anatomy of extrafloral nectaries in Fabaceae from dry-seasonal forest in Brazil. Botanical Journal of Linnean Society 163: 87-98.

Mitchell, J.D. 1992. Additions to Anacardium (Anacardiaceae): Anacardium amapaense, a new species from French Guiana and Eastern Amazonian Brazil. Brittonia 44: 331-338.

Mitchell, J.D. \& Mori, S.A. 1987. The cashew and its relatives (Anacardium: Anacardiaceae). Memoirs of the New York Botanical Garden 42: 1-76.

Morellato, L.P.C. \& Oliveira, P.S. 1994. Extrafloral nectaries in the tropical tree Guarea macrophylla (Meliaceae). Canadian Journal of Botany 72: 157-160.

Nair, G.M.; Venkaiah, K. \& Shah, J.J. 1983. Ultrastructure of gum-resin ducts in cashew (Anacardium occidentale). Annals of Botany 51: 297-305.

Naranjo, H.L. \& Pernía, N.E. 1990. Anatomia y ecologia de los organos subterraneos de Anacardium humile St. Hil. (Anacardiaceae). Revista Forestal Venezolana 24: 55-76.

Nicolson, S.W. \& Thornburg, R.W. 2007. Nectar chemistry. In: Nicolson, S.W.; Nepi, M. \& Pacini, E. Nectaries and Nectar. Springer, Dordrecht. Pp. 215-264.

Nogueira, A.; Guimarães, E.; Machado, S.R. \& Lohmann, L.G. 2012. Do extrafloral nectaries presente a defensive role against herbivores in two species of the familie Bignoniaceae in a Neotropical savannas? Plant Ecology 213: 289-301.

Oliveira, P.S. \& Freitas, A.V.L. 2004. Ant-plantherbivore interactions in the neotropical cerrado savanna. Naturwissenschaften 91: 557-570.

Oliveira, P.S. \& Leitão-Filho, H.F. 1987. Extrafloral nectaries: their taxonomic distribution and abundance in the woody flora of cerrado vegetation in southeast Brazil. Biotropica 19: 140-148.

Oliveira, P.S. \& Oliveira-Filho, A.T. 1991. Distribution of extrafloral nectaries in woody flora of tropical communities in Western Brazil. In: Price, P.W.; Lewinsohn, T.M.; Fernandes, G.W. \& Benson, W.W. Plant-animal interactions: evolutionary ecology in tropical and temperate regions. John Wiley \& Sons, New York. Pp. 163-175. 
Oliveira, P.S.; Rico-Gray, V.; Díaz-Castelazo, C. \& Castillo-Guevara, C. 1999. Interaction between ants, extrafloral nectaries, and insect herbivores in neotropical coastal sand dunes: herbivore deterrence by visiting ants increases fruit set in Opuntia stricta (Cactaceae). Functional Ecology 13: 623-631.

Paiva, E.A.S.; Morais, H.C.; Isaias, R.M.S.; Rocha, D.M.S. \& Oliveira, P.E. 2001. Occurrence and structure of extrafloral nectaries in Pterodon pubescens Benth. and Pterodon polygalaeflorus Benth. Pesquisa Agropecuária Brasileira 36: 219224.

Paiva, E.A.S. \& Machado, S.R. 2006. Ontogênese, anatomia e ultra-estrutura dos nectários extraflorais de Hymenaea stigonocarpa Mart. ex Hayne (Fabaceae-Caesalpinioideae). Acta Botanica Brasilica 20: 471-482.

Pearse, A.G.E. 1985. Histochemistry theoretical and applies. Vol. 2. C. Livingstone, Edinburg. 624p.

Pell, S.K.; Mitchell, J.D.; Mille, A.J. \& Lobova, T.A. 2011. Anacardiaceae. In: Kubitzki, K. The families and genera of vascular plants. X. Flowering plants. Eudicots. Sapindales, Curcubitales, Myrtales. Springer, Berlin. Pp. 7-50.

Pio-Corrêa, M. 1984. Dicionário das plantas úteis do Brasil e das exóticas cultivadas. Vol. 5. Ministério da Agricultura/ Instituto brasileiro de desenvolvimento florestal, Rio de Janeiro. 687p.

Pizzolato, T.D. 1977. Staining of Tilia mucilages with Mayer's tannic acid - ferric chloride. Bulletin of the Torrey Botanical Club 104: 277-279.

Rickson, F.R. \& Rickson, M.M. 1998. The cashew nut, Anacardium occidentale (Anacardiaceae), and its perennial association with ants: extrafloral nectary location and the potential for ant defense. American Journal of Botany 85: 835-849.
Rudgers, J.A. \& Gardener, M.C. 2004. Extrafloral nectar as a resource mediating multispecies interactions. Ecology 85: 1495-1502.

Ruhren, S. \& Handel, S.N. 1999. Jumping spiders (Salticidae) enhance the seed production of a plant with extrafloral nectaries. Oecologia 119: 227-230.

Silva-Luz, C.L. 2011. Anacardiaceae R. Br. na flora fanerogâmica do Estado de São Paulo. Dissertação de Mestrado. Universidade Estadual de São Paulo, São Paulo. 94p.

Silva-Luz. C.L. \& Pirani, J.R. 2014. Anacardiaceae. In: Lista de Espécies da Flora do Brasil. Jardim Botânico do Rio de Janeiro. Available at $<$ http://floradobrasil. jbrj.gov.br/jabot/floradobrasil/FB15463>. Access on 6 October 2014

Stephenson, A.G. 1982. The role of the extrafloral nectaries of Catalpa speciosa in limiting herbivory and increasing fruit production. Ecology 63: 663669.

Vesprini, J.L.; Galetto, L. \& Bernardello, G. 2003. The beneficial effect of ants on the reproductive success of Dyckia floribunda (Bromeliaceae), an extrafloral nectary plant. Canadian Journal of Botany 81: 24-27.

Vieira, M.; Mayo, S.J. \& Andrade, I.M. 2014. Geometric morphometrics of leaves of Anacardium microcarpum Ducke and A. occidentale L. (Anacardiaceae) from the coastal region of Piauí, Brazil. Brazilian Journal of Botany 37: 315-327.

Weber, M.G. \& Keeler, K.H. 2013. The phylogenetic distribution of extrafloral nectaries in plants. Annals of Botany 111: 1251-1261.

Wunnachit, W.; Jenner, C.F. \& Sedgley, M. 1992. Floral and extrafloral nectar production in Anacardium occidentale (Anacardiaceae): an andromonoecious species. International Journal of Plant Sciences 153: 413-420. 